\title{
Male 'Somaliness' in diasporic contexts: Somali authors' evaluative evocations
}

Annie Gagiano

\section{Male 'Somaliness' in diasporic contexts: Somali authors' evaluative evocations}

Addressing five texts by four Somali authors-Nuruddin Farah's Yesterday, Tomorrow: Voices from the Somali Diaspora (2000) and North of Dawn (2018) in juxtaposition with three novels by female Somali authors, i.e. Safi Abdi's Offspring of Paradise (2003), Cristina Ali Farah's Little Mother (201; Italian original 2007) and Igiaba Scego's Adua (English translation 2017, Italian original 2015)-this article assesses the work these texts do to enhance contemporary understanding of the complex, evolving phenomenon that is the diasporic Somali presence in Western Europe, focusing on Somali men. How do the authors portray and (implicitly or overtly) evaluate how diasporic male Somalis cope in foreign, non-Muslim and culturally Western environments-against the backdrop of Somalia's state collapse and social disintegration? Somali men's experiences have generally been given less attention than those of their female counterparts, hence the focus here on male-gendered characters. This focus serves to link the two Nuruddin Farah texts and the three novels by Somali women-a textual grouping and focus not previously attempted in critical studies of Farah's work. This brief essay assesses the five texts' respective combinations of evaluative evocation, affective intensity and epistemological detail, approaching these works as complementing social science researchers' efforts in depicting diasporic Somali men's lives. By deepening understanding of the impact of the diaspora on individual Somali men, the five texts convey significant psychological, social and moral insights into lives of Somali men in foreign contexts. Keywords: Somali men, diaspora, affective intensity, evaluative evocation.

Diaspora and its adjunct states — such as exile, refugee/ism and (most recently) placelessness- are among the most intensively debated conditions of our time. ${ }^{1}$ The diaspora of an estimated two million Somalis from their homeland under the pressures of violent mayhem and state collapse in 1991 (and since) has been approached from a number of contexts. Studies by academic authors from perspectives including cultural studies, masculinity or gender studies, broad literary or African studies, anthropology, psychology, refugee/diaspora or postcolonial studies have been added to historical studies (such as Mark Bradbury and Sally Healey's article "Endless war: a brief history of the Somali conflict"). The 'betweenness' or 'lostness' so characteristic of at least the initial stages (but often lingering effects) of national-cultural displacement cannot be readily captured in a category such as 'postcolonial'; as Erin Glanville writes, the "theoretical intersection between diaspora and postcolonialism hinges on discussions of identity"; she remarks on "diaspora's awkward categorization as a geographical subset of postcolonial studies" (128). Alternative terms such as 'transnational' or 'postnational' are equally unsatisfactory-especially as applied to Somalis, who (it seems) generally continue to identify in terms of a Somali affiliation of some kind. ${ }^{2}$ In an interview Nuruddin Farah stated: "[A]s a Somali I do reside in my Somaliness" ("Nuruddin Farah" 188); while one of Cristina Ali Farah's central characters, in the opening words of Little Mother, reiterates the proud claim of a Somali poet: "Soomaali baan ahay" meaning "I am Somali"—from a "1977 poem by Cabduulaqaadir Xirsi Siyaad, also known as 'Yamyam"' (Little Mother 1). However, it remains necessary (in the words of Stuart Hall) to recognize "identity as constituted, not outside but within representation" (236). Diasporic Somalis, men in particular, have acquired a highly unappealing 'image' - both among fellow Somalis (mainly women) and in the international media. For those emerging from the extremely violent civil war, itself brought about by tyrannical oppression, followed by bloody postwar mayhem and social breakdown - in all of which men were the dominant and directing participants - adapting to Western European dispensations where this negative image of Somali savagery prevails, has proved difficult. Perceptions or experiences of racism and other forms of social contempt

Annie Gagiano is Professor Emerita in the Department of English, University of Stellenbosch, Stellenbosch, South Africa.

Email: ahg@sun.ac.za

(D) https://orcid.org/0000-0003-0812-9215

Dol: dx.doi.org/10.17159/2309-9070/tvl.v.57i1.8077

DATES:

Submitted: 30 April 2019; Accepted: 3 July 2019; Published: 28 April 2020 
towards Somalis in turn provoke resentment against host societies—as a number of social science studies show. ${ }^{3}$ Even mistakenly perceived contempt affects victims (such as members of immigrant minorities): "the insult is received, the slight acknowledged, [...] and the body/mind mobilizes its destructive and devious response in cavernous interiors" (Stokes qtd in Fangen 7l). As Paul Zeleza writes: "African immigrants pay a cultural tax, the devaluation of their human capital in a society where things African are routinely negatively stereotyped and despised" (41). While a "Somali story in the West" may be "an emerging [...] narrative", it remains the case (as both social science studies and literary works by Somali writers reiterate-if not in the same terminology or style) that "diasporic tensions" tend to "racialize black bodies against hegemonic whiteness" (Langellier 89, 69).

For this Nuruddin Farah theme issue, the present article foregrounds firstly his path-breaking work Yesterday, Tomorrow: Voices from the Somali Diaspora (2000) and secondly his recent novel, North of Dawn (2018), in both of which there is greater concentration on experiences and perceptions of Somali men (than those of women) in diasporic contexts. The next part of the article considers Safi Abdi's Offspring of Paradise (2003), Cristina Ali Farah's Little Mother (2011 translation) and Igiaba Scego's Adua (2017 translation) for their perspectives on Somali men also located in various Western European societies, to complete this exercise in "relational comparison" (Shih 431). Shih remarks pertinently that "world literary cartographies can be about the ways in which literary texts from different parts of the world relate to each other as seen through the lens of a specific [...] set of problematics" (434). While it has been noted that "research concerning the situation of Somali men seems scarce in comparison with the well-documented and easily accessible data regarding Somali refugee women" (Svenberg, Mattson and Skott 286), a few good studies by scholars in social sciences making points contextually informative vis-à-vis the literary authors' works are available. One such is the article by Nauja Kleist, referring inter alia to "[Somali] men's difficulties" resulting from "a transfer of male authority to 'the system'-various welfare state institutions-reflecting female empowerment and male misrecognition" (187, emphasis added) - the point highlighted here is frequently reiterated, e.g. by researchers Fangen (87) and Svenberg, Mattson and Skott (286). ${ }^{4}$

In attempting to delineate the particular, complementary perspectives provided by literary authors, the article addresses their affective intensity and powerfully evocative portrayal by means of Maria Pia Lara's concept of "illocutionary force" $(6,19,34)$ : a term she employs to refer to writing that is powerfully moving (emotionally) and achieves vivid characterization and contextualization to "seek a connection with the interests of others" (74). In short, such writing persuades readers to feel concerned about and to recognize the public interest (see her full title) of the topic. Lara suggests that "as agents of cultural contact, narratives work across the boundaries of their own culture, as well as of those cultures that incorporate them" (152) - the latter point especially pertinent to narrative portrayals of persons from minority cultures within diasporic contexts. A political philosopher, Lara notes the effort required to achieve cultural boundary-crossing; she writes that "recognition must come first as a struggle over re-signifying the spaces of appearance" (143 emphasis added).

In his 1998 essay "A Country in Exile", Nuruddin Farah stated that he "developed [his] writing skills in the crucible of nostalgia" at a time preceding the "flood of Somalis [...] seeking [...] refuge somewhere, anywhere!" (713). The important text suggestively titled Yesterday, Tomorrow: Voices from the Somali Diaspora that appeared two years later proves Farah's shift from "nostalgia" to a position of publicly expressed concern for refugee Somalis and the effort he made in using his literary skills to communicate not only his conversations with compatriots in different Western European countries, but his assessments of their situations and his reflections about the significance of what had happened to them (and to himself) in Somalia and in the diaspora. The text is dedicated "To Somalis, whoever and wherever they are" and to the memory of a dear friend. It is a deeply moving document, written under the sign of a shared loss, despite the author's often hard-headed questions and the fierce moral and political criticism that he interweaves with renditions of testimonies of suffering imbued with unspoken compassion. Initial interviews (evoked in the next sentence and the paragraph below) took place in Kenya. Sometimes Farah's bare reporting-e.g. of a fifty-year-old man describing his own torture, in which the thought of "his female folk, all raped, including his four-year-old granddaughter" (11) - is the most appropriate way of referring to atrocities.

The "illocutionary force" in one dignified middle-aged man's words enables Farah (and the reader) to grasp the particular kind of mayhem that overtook civilized life in the formerly cosmopolitan capital city, Mogadishu, and why there was no choice but to flee from there. The interviewee describes "violence-as-a-spectacle", "a substitute for elusive power" and a manifestation of "power-greed, pure and simple" that "turned [the city] into an abattoir" $(16,17)$. Farah notes elsewhere in Yesterday, Tomorrow that years earlier (in 1978) when he and his parental family were forced to evacuate their home in the Ogaden region, Mogadishu had been their "new place 
of refuge" where they could "reconstitute [their] identities from an idealism [rooted in a 'newly' developed] sense of nationalism" (50) - in stark contrast with how conditions in the city impinged on other Somalis in the 1990s. Evoking the somatic response of an interviewee, Farah describes how in "the pain of fresh memory [...] his whole body began to tremble", registering "an anger fiercer" than his "pain" (18). The man's eight-year-old niece, a rape victim whose parents were murdered in her sight, is with him; the girl is speech-impaired. Farah witnesses the "well of tears" expressing this man's "sorrow"-himself struck silent. By contrast, a former member of one of the youth gangs that roamed Mogadishu boasts that he has "no regrets" for the murders and mutilations "of men and women" and horrific "humiliat[ion] of minors" that he committed. Safi Abdi has a comparable character-incongruously named "Little Hirsi" (198) — who calmly admits to "nine years of shaitanic merriment" (devilish jollification) during this time.

Another clear contrast between admirable and despicable attitudes among diasporic Somalis features in the seventh chapter of Yesterday, Tomorrow (66-76), contrasting the enterprise, self-sacrifice and familially responsible conduct of an educated Somali woman who, in Italy, works in house-keeping, with that of her four unemployed, "lie-abed" brothers (71) whom she accommodates in the flat she rents. For each of her six siblings' smuggled transfer from Somalia she paid 3,000 dollars from her savings, yet the men refuse to do "degrading" paid housework to contribute to their upkeep. No wonder the sister (a former school headmistress) refers to her brothers and others like them (along with her female friends) as "exploiters, liars lazybones" (76). When she rebukes her brothers for "the mess they had created" (70) in her flat, readers recall an older Somali man's reference to post-civil war Somalia as a "tragic mess" (14). Evident authorial disapproval of such parasitical male conduct in young men contrasts with seemingly more "forgiving" attitudes permeating researchers' accounts of male status loss in the Somali diaspora. Farah's disdain is probably understandable in terms of his own willingness to 'reinvent' himself when it was no longer possible for him to return to Somalia and he found himself stranded (penniless) in Italy, working in all sorts of employment to pay his keep, like other interviewed Somali men prepared to work in lowly jobs in contrast with former high status employment in Somalia, also contrasting with the conduct of "layabout" men - mainly younger, uneducated and unemployed, even at home. Another older man concerned with maintaining "tradition" (87) insists that although General Muhammed Siyad Barre was indeed "an evil dictator", responsibility for the country's ruin lies with the entire Somali people, "since we, as a nation, did not safeguard our sense of nobleness" (88). Another man's acceptance of communal responsibility (he "runs a mosque principally for the Italian Somali community" in his "spare time" 91) contrasts with the sinister, predatory figure of Imam Yasiin in North of Dawn, but resembles the devout, humane leader Abdirahman in Abdi's Offspring of Paradise. ${ }^{5}$

What has been termed the "psychic loss" (Gagiano, "Surveying the contours of 'a country in exile': Nuruddin Farah's Somalia" 259) suffered by Somali refugees is illustrated in the example of "an elderly Somali" whom Farah (Yesterday 167) describes as "a pillar of his community". The man came to Sweden as "the head of a family", experiencing his newly low status and the endless bureaucratic delays of being 'processed' into the local system as "very, very embarrassing and difficult"; "hostile to one's honour" and "destr[uctive to] one's soul"-only to find himself later "a shooting target [for Swedish] youths". The police, to whom he reported the pot shot, never returned his call. Another of Farah's interlocutors does admit that "We Somalis have a penchant for attracting negative publicity, and act as though we were a nobility in exile"' (174). Still, even though the Somali youths loitering in noisy groups at the stations are resented by the hardworking Swedes who know their subsistence is state-paid (they probably never worked in Somalia, either), Farah more forgivingly surmises that "they were busy, taming their sense of alienation, entombing their despair" (175). Compare Taageere, one of the three main narrators in Cristina Farah's Little Mother, who does do lowly work abroad although he seldom keeps these jobs. In Sweden, the refugees are, in any case, not allowed to work without "personal numbers" (174), hard to obtain. The worst experiences to which Somali refugees in Sweden are subjected (described as "harsh", "inhumane", "claustrophobic" and even "subhuman") are conditions in "camps" set up for refugees (175-8). Such experiences confirm the melancholic observation of a refugee who had been "one of Somalia's well-known cineastes" (42): "a nation in distress is accorded no respect among other nations"' (44).

Sadness permeates the lives of the Somali refugees so compellingly evoked in Farah's text. In Yesterday, Tomorrow he over and over draws attention to the incurable sorrow particularly as felt by older men-thus pointing forward to Mugdi, the main narrator of North of Dawn, who "thinks of himself as a man born to grief" (13). Farah himself, contrastingly, asserts several times in the course of the earlier text that he is not a refugee, whom he defines as "a person who has lost the ability to express the fullness of his being", since as a writer he "is no refugee". 
He has moreover taken on a great task - that of "keep[ing his] country alive by writing about it" (50). His "imaginative powers" have "afford[ed him] the privilege [of] creat[ing] another country" out of his "displacement" - the condition he admits sharing with his refugee compatriots (49). Farah has remained faithful to his "vow" to continue, despite obstacles, to write "about the destiny of the Somali nation" as "a Somali exile writing about Somali refugees" (127). He transforms "the deep depressions of an exile" through "creativity" (192-3). The profound caring Farah evinces for Somali refugees is unforgettably conveyed in Yesterday, Tomorrow; demonstrating Lara's remark that "the aesthetic effect of 'disclosure' can provide a new way of understanding justice" (5).

Farah's novel North of Dawn appeared 18 years after Yesterday, Tomorrow and evokes diasporic male Somali lives contrasting with those depicted in the earlier text. It is much closer to a single-voiced text than Farah's usual literary practice, with the former Somali Ambassador Mugdi (living in Oslo) the dominant narrator. Unusually (for Farah), its female characters are quite sketchily presented. The title North of Dawn possibly alludes to the Nordic setting and the text's muted, often gloomy tone. The fact of Islamic terrorism is the work's context and preoccupation, centering on Somali men's attitudes concerning this internationalized, shrouded war. Yesterday, Tomorrow's main Dedication to all Somalis contrasts with North of Dawn's to a single Somali victim-Farah's sister Basra, "killed [in 2014] by Taliban terrorists" in Afghanistan. Linking directly with this is the novel's opening sentence: "IN SOMALIA, THE BOMBS HAVE BEEN GOING OFF FOR MONTHS, ROADSIDE devices killing and maiming anyone unlucky enough to be in the vicinity" (1). Whether the [originally] capitalized opening line is a typesetting accident, or an intended effect required by the author, is unclear, but the shocking impact would be much the same if lower case lettering were used. The disgust evinced at the evidently indiscriminate nature of the killings is Mugdi's, but aligns him in grief, fury and horror with the author and endows this expatriate male Somali's voice (he is no refugee, though diasporic) with authority. ${ }^{6}$ The novel is in my view the weaker for the extent to which this alignment corroborates a didactic purpose, whereas it makes the main character's weaknesses and faults (and information gaps in Farah's portrayal of him) difficult to interpret. Mugdi appears to have remained an ambassador for the tyrannical Barre government until 1988, but this association is not used to tarnish his imagecontrasting with Yesterday, Tomorrow's authorial exposure of former Barre government profiteers through probing questions and cutting comments. ${ }^{7}$

Mugdi and his Somali wife Gacalo (who works in a Government Department) live largely in isolation from other Somalis, with the exception of their dear friend Himmo and her three children. In her inconsolable mourning for their only son Dhaqaneh, who killed himself in a suicide bombing in Somalia, Gacalo insists on bringing her son's widow and two stepchildren to Norway - an expensive and dubious plan. She goes an extra mile to fulfill her promise to Dhaqaneh - a section leader of the al-Shabaab terror group - that she would "look after" his family if he died. Mugdi opposes what he evidently foresees as an unwelcome, intrusive and risky disturbance to their somewhat placid lifestyle. Gacalo in the ends kills herself, her grief seemingly intensified (125) by her realization that their son's widow's presence has seriously compromised them in her formerly unsuspected association with al-Shabaab terrorism. Mugdi goes on to a new life with a new (Norwegian) female partner. Despite occasionally indicating a (not terribly deep?) sense of carrying some responsibility for Dhaqaneh's radicalization and stating "regret" (not guilt) at having partly blamed his wife for this (180), Mugdi's general self-righteousness is unappealing. There is also a clear contrast between his kindly, tolerant and loving way of treating his step-grandson Naciim (who is perhaps 'too good to be true') and his either neglectful or puritanically disapproving (past) attitude towards his teenage son. Mugdi's supportive role in Naciim's life may be read as unconscious, belated compensation for his paternal failures with Dhaqaneh (177), for whom he admitted caring less than for his daughter Timiro (58). Especially revealing is Mugdi's disquieting feeling that he "should be sorrowing over [...] [a destroyed] Somalia" instead of being "concerned about the death of a son or the arrival of a widow" (14, emphases added). The point is disquieting in that it is surely normal to care at least as much about one's only son's death as about one's country's ruin (and most people would care more about the loss of a child). Readers are left wondering why Mugdi has never "fully [...] shared" with Gacalo what exactly "happened between father and son" when he and Dhaqaneh had their final, furious quarrel before the latter conclusively left Norway. Dhaqaneh is likely at the back of Mugdi's mind in the remark that "It has always disturbed Mugdi that Somalis in Norway tend to attract bad press, and seem relegated to the lowest rung on the economic ladder, unable to see beyond their ideological and religious constraints", whereas "he feels certain that Naciim and his generation of fresh-faced ambitious young Somalis will change all that" (177). 
Naciim's clearly approved emotional and intellectual growth in Norway; his appreciative and graceful adaptation to conditions in this country and fondness for his 'local' relatives, make him the next most fully portrayed male Somali in this novel (after his mentor, Mugdi). He is open-minded, eager to learn, sensitive, perceptive, intensely intelligent and impatient of ideological rigidities. While generally convincingly portrayed as a charming youngster, Farah occasionally overdoes Naciim's idealization (as one may see it) - as when the boy's enjoyment of his first Norwegian winter is described as "frenzied joy" (307) and when he makes a quite priggish speech to his mother about Somalia's once "good" people (when his mother was young) regressing into a state where "the weak are massacred with impunity." He tells her that Somalis "pay lip service to the [Islamic] faith [...] [and that this is] why the strife in our land rages on unabated" (349-50). The sentiments are indeed valid, but the voice is not Naciim's own, appearing ventriloquized. ${ }^{8}$ The boy seems unmoved when seeing off his mother for probably the last time (admittedly she had endorsed his recent brutal, unjust flogging by Imam Yasiin), but even uncaring about his sister's grief at the parting - describing both of his closest female relatives dismissively as "these weepy women in all-black body tents" (367). Farah adds a kind of endorsing detail two pages on, when signs of the mother's probable absorption into al-Shabaab are reported to Mugdi by Naciim.

Little narrative space is allowed to evocations of Dhaqaneh. Since Mugdi's voice dominates the narrative, readers get few glimpses of him untinged by Mugdi's detestation of his son's ultimate ideological choices and acts and his earlier disapproval. Quite innocuous and typical teenage behavior that raise no eyebrow with Mugdi in Naciim, are evoked as repellent in his son (e.g. watching pornography, and fighting back when attacked by neo-Nazi gang members). Interestingly, Naciim speaks out to describe Dhaqaneh angrily stopping desecration of "enemy" (non-Muslim) remains in Mogadishu — even at a dinner-table in Norway where members of al-Shabaab (which Dhaqaneh had joined) are referred to as "barbarians" (179). In contrast with Imam Yasiin-who clearly took sadistic pleasure in administering fifty lashes to Naciim in unjust chastisement-the boy recalls only "smacks" from his stepfather (53) to discipline his boyhood transgressions, while it was Dhaqaneh who taught him chess and a love of reading. He also had no inkling that (his stepfather) "the man whom he had loved and called 'Dad' was a terrorist" (236), thus Dhaqaneh had never indoctrinated the boy with al-Shabaab ideology. This indicates responsible fatherhood, although it is said to be the group's practice to keep family members ignorant and unaware of their participation in its activities.

Minor male diasporic characters (in Norway) are stereotypically evoked and often dismissed with a labelapart from the awful, fanatic Muslim cleric Yasiin, an elderly man lusting after Saafi (Naciim's teenage sister), we have Mugdi's son-in-law Xirsi-soon divorced by his pregnant wife Timiro and dismissed as a "scoundrel" (190) by both her parents - and Imam Yasiin's deputy Zubair, a friend and al-Shabaab comrade-in-arms of Dhaqaneh, who beats up and soon secretly marries Dhaqaneh's widow Waliya and whose "shifty eyes" (123) repel Gacalo. Zubair is arrested for his links with Muslim terrorists. He is something of a parallel figure to Dhaqaneh in being to some extent a similar product of deficient parenting - a version of Zubair's 'history' in Norway is related to Gacalo by Himmo (109-13). In fact, the cursory dismissal of the above figures (along with the obese drunkard and bore Suudi, shown attending Gacalo's wake, 266) seems harshly one-sided. Mugdi's younger brother Kaluun-a privileged diasporic (like his brother) - proclaims that, because they are routinely despised for being "Muslim and black [...] the onus is on Somalis to improve their chance of success wherever they are"' (224). In this rather snobbish remark, North of Dawn contrasts with Farah's more balanced, nuanced portrayal of diasporic Somalis in Yesterday, Tomorrow. Contrast Farah's denunciation in the earlier text (54-5) of "the racist logic to the immigration laws" of Europe (55).

Unlike Farah's truly impressive earlier old man characters-such as the political hero and deeply spiritual Deeriye in Close, Sesame (1983) and the magnanimous, life-loving Nonno in Secrets (1999), Mugdi's is a rather pinched soul. For example, Mugdi tells his Norwegian friend Johan, after Gacalo's death, that he and she had "had no problem severing all ties with Somalis, including those who are here [in Norway]" (259)—and in his case (unlike Gacalo's) even with their own son. His endlessly unfinished, futile-seeming literary translation efforts appear unlikely to contribute much to Somali-Norway bridge building. In this he contrasts with his prolific author, Nuruddin Farah, who unflaggingly pursues a writerly duty to increase understanding of the unfolding Somali national saga - or tragedy. In comparison with Yesterday, Tomorrow, it seems unlikely that Farah would say of this somewhat bloodless novel (as he had concerning the compilation of anguishing Somali testimonies in the earlier text) that it was "not an easy book to write" (Yesterday vii-iii). The impression stems from the predominantly 
calm, low-key tone of the dominant voice in North of Dawn-Mugdi's, giving it lower "illocutionary force", as if (for him) Somalia has been 'written off'.

In Safi Abdi's novel Offspring of Paradise (2003), the voice most clearly articulated is the adolescent girl Hana's - and even though few depictions of diasporic Somali males feature in this text, the girl's fury against Somali men (and what it stems from) permeates the novel — which can be seen as taking up a moral enquiry. Abdi's novel has been read along with Cristina Ali Farah's Little Mother and Nuruddin Farah's Knots as being "gynocentric" and "condemn[ing] what are perceived [...] as the phallocratic [...] swaggering, ruthless and competitive 'macho' culture ascribed by the [mostly female] characters to a majority of Somali men [who are held responsible for] [...] the destruction of the country as a liveable location"" (see Gagiano, "Three Takes on Somali womanhood in the eddies of the Black Atlantic" 279) $)^{9}$ As a six-year-old girl, Hana witnessed her beloved father pulverized when a hand grenade blew him apart in the onset of Somalia's internecine violence. Her father's brother, who assumed the paternal protector's role to try and drive Hana, her pregnant mother and her elderly grandmother to safetybecause their family were seen as belonging to the 'wrong' (Barre's) clan-was shot and killed by roaming clan vigilantes; young thugs who seized their vehicle and proceeded to gang-rape her mother. Her mother went into shock labor and gave birth to a dead boy; crazed by the horrors inflicted on her, she crawled away in the dark night and little Hana was left to help her grandmother bury the dead. Years later, when Hana is living with her grandmother in a refugee center in an unnamed but obviously Western country, she sees her lost mother and dead sibling in the televised images of Somali women and children "with ropes for arms", whispering: "Her baby will die" (ll). Hana's generalization — casting all Somali women as victims and Somali men as evil—is validated by Abdi's narrator in informing the reader that "clan cleansing" escalated "into a wholesale bloodbath", adding: "the killing and maiming of all forms of life became the norm, and the dishonoring of women an honorable feat" (17).

Abdi engages in an interesting way with international condemnation of the brutalities of the Somali Civil War. Hana's symbolization of Somali men and women as contrasting emblems of innocence and guilt is validated by first-hand experience and unlike apparently similar, yet cursory generalizations by some earlier researchers. ${ }^{10}$ Nevertheless, when the girl's Ayeyo (grandmother), her succor and mainstay, passes away, it is only Abdirahman, a man who has assumed the spiritual leadership role in the small Somali refugee community, who can prize Hana's hands from the body and counsel her comfortingly to accept Allah's will. Abdi's representation of Abdirahman as a man of deep faith, integrity and sensitivity to refugees' plight endorses the small diasporic Somali community's sense of his stature.

The narrator describes the Somalis who live in "The Wall" (as the refugee center is dubbed) as "inter-related", adding that "they alone could make [sense] of what drove them into that wall" (original emphasis): each one of them "carried a [...] wound ... a personal scar that sensitized only that entity, and none else. Each entity hating the warlord of the other, yet caring for each other in spite of the warlords" in a "love-hate relation that only a victim of Somalia's present condition could feel or even hope to understand" (80 original ellipsis). Of the two young male Somali refugees evoked in the novel, one helps to push Hana into a fanatic "Christian" woman's clutches, while the other helps to rescue her from this monstrous person. Both are former victims of the (white) woman's indoctrination; one frees himself while the other-the abovementioned "Little Hirsi", who is unrepentant about yet haunted by the violent deeds he committed as a member of a Mogadishu youth gang-slyly exploits the "Christian" woman and her organization's aid to help fund a warlord in Somalia. Abdi's unusual, passionate writing carries persuasive power and adds nuance to our sense of a morally bewildering condition that troubles Somalis and puzzles outsiders.

One important conversation with Abdirahman somewhat softens Hana's reproaches when this "upright" man breaks down in tears, showing himself "remorseful"-in Hana's description and to her surprise (235). She will not give up her fight for Somali women, challenging Abdirahman with fierce questions: "How many times have you good guys of all [Somali] tribes ever met over tea and mourned for the children of our nation? And when was the last time you put yourselves in your mothers' shoes?" (236; original emphasis). These questions suggest a fierce view of most Somali men as morally tarnished, despite Abdirahman's plea for forgiveness, and Hana's memories of her father and uncle.

Condemnation and accusation of "Somali men" in texts like the above link with Svenberg, Mattson and Skott's observation that "research regarding the situation of Somali refugee men seems scarce in comparison with the well-documented and easily accessible data regarding Somali refugee women" (15). Cristina Ali Farah's Trans. Little Mother (original Italian title Madre piccolo) does indeed give considerably more space to the voices of her two 
principal female characters, cousins who as little girls lived as sisters, but her portrayal of Taageere (whom Domenica Axad later marries) is much more detailed and extensive than Abdi's evocations of relocated Somali men. The diasporic male the reader first encounters in Little Mother is mute, injured and under police guard in the hospital where Barni, the title character, works as a midwife. From a sense of the burnt man's resemblance to her cousin Axad's father, and because her own mother died in a fire, as well as in recognition of the "traumas" (23) he must have suffered, Barni feels connected to the man. She tries to help the injured stranger and addresses him in Somali as Walaal (brother). Only later does she find out how heroic a role the man had played in the life of Luul, Taageere's vulnerable younger sister, who had given birth in an old car on a street in Rome. Maxamed had got badly burnt when he self-forgetfully rushed to the rescue of Luul and her newborn, believing them trapped inside the wreck when it caught fire - only to incur local police suspicion that he is a "terrorist." "l

Maxamed as an admirable man contrasts with authorial evocations of Taageere as immature, irresponsible and feckless-even though Cristina Ali Farah's character evocation is neither unempathetic nor uncomplicated. It is a particular accomplishment of this text that Taageere is portrayed at once so vividly and in so nuanced a manner. The first chapter of three conveying Taageere's voice evokes his hectoring phone call to his ex-wife Shukri; a monologue both hilarious in its emotional ineptitude and deplorably sexist (51-85). Only at its end does he reveal the real reasons for his call: that he has married a second wife (Domenica Axad) who holds an Italian passport, but that without having Italian divorce papers to prove the annulment (done by Muslim rite and over the telephone) of his first marriage, this second union cannot legally facilitate his re-entry into Italy. Farah does not allow the reader (or Domenica - as Taageere always refers to her) to be sure whether his second marriage was merely a ploy to allow his return to Rome-where his ex-wife lives with their nine-year-old son (whom he has never seen, Taageere having left Italy before their arrival) and where Luul (his younger, newly widowed sister) has now also arrived and given birth. Acknowledging her "suspicion" about Taageere's true nature and real motives (and having discovered his disingenuousness in not informing her earlier of his previous union), Domenica Axad appears unperturbed about building a life in Italy with her little son and Barni as a co-parent, without Taageere. Yet she accounts for his initial strong appeal to her by describing how undemanding she found his company. Despite sensing his incapacity for "responsibilities" and his "weak will", she felt able to reveal her full self to him, "unbridled" and trusting in his seemingly uncomplicated nature (116). The reader (and probably Barni) can recognize that Axad is implicitly contrasting Taageere with their mutual cousin Libeen, who took charge of her life in a stiflingly domineering manner when she became emotionally unmoored after her frustrated attempt to return to Somalia on the eve of their country's collapse. She lost the chance to reunite with her father, who since died in the conflagration. Libeen's controlled and controlling manner ensures his own success in "the West" (Holland), but his patriarchal temperament is ill suited to Axad's freer spirit.

Libeen also contrasts with Taageere because the latter is much more conscious of having been detrimentally affected by geographic and cultural transplantations. Authorial empathy for Taageere is evinced in the power of the expressions conveying his pain, such as his reference to "a deep and shabby sadness" reminiscent of the "sorrow" dominating refugees' lives noted by Nuruddin Farah (Yesterday viii). Taageere's shame at his own "dirty" state (57) and his exilic loneliness are expressed as "rage" and "[self-]disgust" (84). Taageere's psychic uprooting exemplifies how "life in exile has entailed not only a loss of language but also a deficiency of cultural anchorage" (Lilius qtd in Svenberg, Mattson and Skott 286) and resembles its effect upon Domenica, suggesting affiliation between them. His drug peddling, his foolish money-making attempts and unappreciative reliance on other Somalis housing him, combine to paint him as a loser undeserving of sympathy; nevertheless, Cristina Ali Farah balances this impression by allowing Taageere's voice the opportunity (in her novel's central chapter) to speak a moving lament for Xamar-as Somalis call Mogadishu, the cosmopolitan core of a former gentle, widely shared Somali culture and civilization (Little Mother 120-7). ${ }^{12}$ An especially endearing aspect of Taageere's character is his generous willingness to help those he cares for and to take risks on their behalf; his tenderness towards women in need and children and his great sorrow at the violent death of his dearest friend-killed in a haphazard shooting by one of the packs of young, drugged thugs who roamed Mogadishu's streets after Barre's downfall. While Libeen, Barni's ex-husband and Taageere's friend Saciid Saleebaan allow clan dictates to enter their lives and destroy love relationships, even abroad, there is no sign that Taageere has interest in this ethos or its violent manifestations.

At the end of this novel, Domenica Axad decides that her (and Taageere's) son must be circumcised, "to mark his belonging [as Somali and Muslim] on his body" (223). Through the child, she and Barni reconnect with their uncle Foodcadde (a family rather than a clan elder), and also with Domenica's Italian mother-straddling cultural 
divides. The baby is named Taariikh in a symbolic revival of Axad's admirable father, lost in and to Somalia's harrowing collapse, but perhaps auguring a more hopeful future for diasporic Somali men where admirable, familially and socially responsible conduct will no longer be exceptional. Mugdi's expressed conviction that, despite most Somalis faring badly in Norway, "unable to ever really advance [...] he feels certain that Naciim and his generation $[\ldots]$ will change all that" (177), corroborates this impression.

Igiaba Scego's novel Adua proceeds from very different premises, looks at a longer history of Somali diaspora and uses a "diary entry" style in order to juxtapose a father's and a daughter's experiences as Somalis in Italy. Adua originally appeared in 2015; the English translation in 2017. As Zeleza remarks, diasporas change over time: "the emotional and experiential investment in 'here' and 'there' [...] in their [various] complex intersections [...] changes in response to the changing materialities, mentalities, and moralities of social existence" (32). Zoppe's and Adua's respective experiences of diasporic existence illustrate the point: Zoppe's during the 1930s and Adua's from 1977; hers perhaps concluded by a return to Somalia in the present to parallel her father's, earlier. Marta Ghiroldi distinguishes between "female experiences of migration" involving mainly "body, violence and depression" and "male migrants' experience" in which "humiliation and [...] the feeling of danger as a constant element" predominate (51). ${ }^{13}$ Indeed, "humiliation" more than physical pain is mentioned on the novel's first page, evoking Zoppe's brutal assault by three Italian soldiers. However, both father and daughter experience what Fongang identifies as "the overwhelming social isolation of African migrants in various metropolises of the West" ("Cosmopolitan Dilemma: Diasporic Subjectivity and Postcolonial Liminality in Teju Cole's Open City" 145). Zoppe had dreamed of getting to Rome; delighted at the opportunity to do translation work for the Italian army in the great city. Well groomed, educated and plurilingual, he is reduced to a butt for the blows of the soldiers to whom he is a mere "dumb nigger" (7). Ironically, as a boy, "in Mogadishu he felt like a foreigner"—disdained as a yokel from the south by locals (138). Only when he returns to Somalia from Italy, many years later (though still in the service of the Italians on the eve of the Abyssynian War), will Zoppe grasp that in doing his translations, he betrayed his fellow Africans $(148,163)$. His decadent, aristocratic employer Anselmi forces Zoppe to wear a blue turban like a colonized Sikh—a garment he finds humiliating, like the nauseating suggestion (vaguely hinted at) that he will be made to "serve" Anselmi sexually (79), possibly infecting him with an STD (90).

Having exhibited Zoppe's eventual acknowledgement of the shameful part he played as a servant of duplicitous, ruthless but powerful Italians, Scego indicates that this realization probably facilitated Zoppe's partial moral redemption in his later castigating of the tyrannical effects of Barre's embrace of Russian Communism - at the cost of incarceration. This brave, politically risky stance exhibits how diasporic experience had morally educated Zoppe through his sufferings (94). Adua, who had not understood her father, nevertheless stole "the blue turban he always wore" (98) to wear as a keepsake, in Italy-unaware of Zoppe's dream vision, years earlier, that made him see this "hate[d] turban" as a symbol of his betrayal, which he thus wore in penance (146-7).

One other diasporic male plays a significant but somewhat lesser role in Adua's later life in Rome-the young man she (middle-aged by then) marries: "he was a Titanic, someone who'd risked drowning at sea to come" to Italy, who needed (in Adua's words) "a house, a teat, a bowl of soup, a pillow, some money, hope [...] relief. He needed a mama, a hooyo, a whore, a woman, a sharmutta, me" (21). ${ }^{14}$ In return, the young man gives Adua sexual attention, comfort, companionship and compliments. ${ }^{15}$ She cooks Somali food to please him and brews his favorite shaah (Somali herbal tea), well aware that one day he will move on, and indeed pays for him to do so by the end of the narrative. Ahmed is furiously indignant when by chance the porn film in which Adua acted (as a young, newly arrived woman in Rome) is broadcast on TV; unable to recognize the parallels between their respective refugee situations. Yet he is concerned for her honor and shows loving appreciation when, upon his departure, he gives Adua the gift of an expensive video camera, saying: "Now you can [...] tell your story however you think"' (171). This is strongly reminiscent of Libeen's gift, also of a video camera, to Domenica Axad in Little Mother - and she, too, uses it to tell her own story and create her own documentary account of the lives of diasporic Somalis. The incident concludes the novel by aptly and deftly intertwining Adua's story with that of her father. Like him, she had worn the turban as a type of expiation; she calls it "the sign of my slavery and my old shame"; "the yoke I had chosen to redeem myself" (170). Before he leaves, Ahmed explains that, by not retrieving the turban, he had helped Adua to free herself from her past and her guilt-Scego thus depicting sensitivity, generosity, gender awareness and political sophistication in a young, expatriate male Somali. 


\section{Conclusion}

"I don't think any nation is saved by one book", Achebe wisely warned, years ago (25). Whilst none of the featured works can 'save' diasporic Somalis and solve their individual and communal problems, yet-individually and as a composite 'mosaic' of implicit analyses vividly evoking impressions that convey moral evaluation and socio-political insight along with understated psychological interpretation - the writing contributes uniquely valuable knowledge concerning Somalis of the diaspora. The present article focuses on male exiled Somalis as an as yet under-analyzed topic in both African Masculinity Studies and Diaspora Studies and exhibits how these intersect with literary aesthetics. A majority of Somali writers (Nuruddin Farah, Abdi and Cristina Ali Farah among them) place men at the heart of the diasporic community's problems of adaptation, also holding them primarily responsible for the country's collapse into violent anarchy and the lingering problem of Somali disunity. While this point is not contested by the chosen texts, their portrayals insist on the non-hegemonic nature of diasporic Somali masculinities. Somali women may adjust better than their male counterparts in the diaspora, but women need the co-operation of the men with whom most of them share their lives.

The works discussed compellingly prove their authors' profound commitment to deepening Somalis' as well as international understanding of the handicaps incurred and opportunities created by diasporic Somalis, while depicting the extent to which they remain bound to and haunted by their country's plight. Mugdi's wise reply (in Nuruddin Farah's North of Dawn) to his step-granddaughter Saafi's question why Somalia is taking so long to recover from its "[collapse] into total anarchy", tells her (and her brother) to consider that an "implosion" of such "magnitude" has had "repercussions for every [single] Somali"-including those who had "sought refuge in other lands". All are "haunt[ed]" by its "seismic consequences" and because "the disintegration of Somalia" is "still unfolding" - adding that the "oblivious" world has been unable to "decipher the signposts" of the disaster (293-5). Mugdi's words apply as a description to the insights all five novels addressed here, convey-and likewise to the "illocutionary force" of these compositions.

Although we must avoid "fencing off migrant literature" from its connections with people and writers in the homeland, as Giuliana Benvenuti cautions (133), combined efforts of many writers and social agents-in both literary work and across disciplines and professions - are needed if we are to address intractable seeming issues of pernicious conflict and arduous social readjustments required in the wake of its dislocating effects, which texts like the five evoked here compellingly convey.

\section{Notes}

1. Lyndsey Stonebridge's Placeless People: Writings, Rights and Refugees (2018) examines how the changed and changing notion of "exile" and its gradual devaluation was registered by earlier twentieth-century writers such as Arendt, Kafka, Orwell and Beckett. The Postcolonial Subject in Transit: Migration, Borders, and Subjectivity in Contemporary African Diaspora Literature (2018) edited by Delphine Fongang features no Somali authors.

2. Bill Ashcroft's "transnation" concept accords, he believes, with "the smooth spaces [of] memory" (as contrasted with "the striated space of history" that accompanies "the nation state and all structures of fixed identity" (83). However, even as diasporic Somali "identity" is not "fixed", it remains bound to memories both of the destroyed Somali "nation state" and the painful (rather than "smooth") personal acts and moments of recollection with which these remain entangled. In his book on Nuruddin Farah and B. Kojo Laing, Francis Ngaboh-Smart describes Farah as a "postnational" writer (52). I argue that, without being a Somali nationalist, Farah retains a Somali national affiliation. Compare Frantz Fanon's warning against leaders of "underdeveloped countries [who] imprison national consciousness in sterile formalism" (165) and his insistence that "national consciousness [...] is not nationalism", since "it is at the heart" of the former "that international consciousness lives and grows" (199).

3. Especially impressive because this very detailed and carefully constructed study conveys an impression of the researcher's empathy is Katrine Fangen's "Humiliation Experienced by Somali Refugees in Norway", in which "humiliation" is associated with "discrimination, exclusion, derision, and stigmatization" (70). Compare Haideh Moghissi's observation referring to diasporic Muslim men's "deep emotional vulnerability" and her statement that "the sense of insecurity is sometimes expressed through hostile reactions to the host country" $(3,4)$.

4. Assessments of "African Masculinities" such as Ouzgane and Morrell's 2005 collection are broad (generalising) assessments or focused on other (non-Somali) masculinities, while a more recent article concerned specifically with "transnational" African Masculinities notes that "in the UK, African migrants, particularly men, have been positioned as significant 'problems' within the media, political, and health discourses", adding that these trans-national "African masculinities are somehow captured through an Orientalizing gaze as immutable, violent, patriarchal, and oppressive" (Pasura and Christou 527). The latter finding comments broadly on African men in the UK and, while pertinent to noted perceptions of Somali men elsewhere in Western Europe, is not specific to men from Somalia.

5. Masterson (in an otherwise excellent study of Yesterday, Tomorrow) mistakenly asserts that "fathers and husbands are invariably shown in neglect of their responsibilities" (233, emphasis added). Farah's text is more balanced in its depiction of Somali men than this generalization suggests. 
6. While Farah's sister was the victim of Islamic terrorism, Mugdi's son died as a terrorist participant and is held responsible by Mugdi for many terrorist murders (never detailed).

7. On p. 14, it is unclear whether it is Mugdi's "detest[ation of] Somalia's dysfunction" (a euphemism?) or the governmental "dysfunction" that is referred to as "unrelenting since 1991" - when Barre fell. Farah from as early as 1976 explicitly opposed the Barre government, unable for years to risk returning (Yesterday 58), whereas by contrast Mugdi seems to have continued using his Mogadishu flat up to 1990.

8. In Offspring of Paradise, Hana's revered, sage-like Ayeyo (grandmother) expresses a similar point (113), but her deep piety is convincingly established before this. So is that of Abdirahman, the community leader who teaches Hana: "We cannot blame [the Somali] tragedy on Islam. [...] Rather, it's the lack of true Islam"' (235).

9. Nuruddin Farah's recurrent denunciation of Somali patriarchy and misogyny have been widely noted—see in particular Alden and Tremaine's chapter (123-56) and Juraga's "Patriarchy" (283-7).

10. Pauline Ada Uwakweh statement outlines this (fortunately, increasingly outdated) practice: "A notable problem in African migration studies is the tendency of researchers to essentialize Africans, thereby imputing monolithic characteristics on African migrants" (4).

11. Taageere's conduct in Italy and the USA accords with Nuruddin Farah's reporting about diasporic Somali males' parasitical, dirty, lazy quaat-chewing habits (Yesterday 66-76). Nevertheless Cristina Ali Farah's Taageere is a more complex portrayal (Gagiano, "Three Takes" 295).

12. Compare (in Abdi's novel) Mulki's memories of life as lived in a once "peaceful Somalia" (108-9).

13. Once again recalling Fangen's fine study on more recent forms of "humiliation" that refugees experience

14. Compare Barni's powerfully affective, nightmare visions of the victims of these dangerous journeys as discussed by both Gagiano ("Three Takes") and Tembo.

15. Their marriage is not frowned upon by other Somalis in Rome, Adua testifies, since everyone understands it as a mutually beneficial arrangement. In contrast, Nuruddin Farah reports that Somali women working in Italy, while expected to house any and all unemployed male relatives, are harshly denounced as "tagsis" if they provide accommodation for lovers unrelated to them, or non-Somalis (Yesterday 76; original italics).

\section{Works Cited}

Achebe, Chinua. "Mapping Out Identity"-An Interview with Chinua Achebe. The Classic vol. 3, no.1, 1984, pp. 24-5.

Abdi, Safi. Offspring of Paradise. lstBooks, 2003.

Alden, Patricia \& Tremaine, Louis. Nuruddin Farah. Twayne, 1999.

Ali Farah, Cristina. Little Mother. Trans. Giovanna Bellesia-Contuzzi \& Victoria Offredi Poletto. Indiana U P, 2011.

Ashcroft, Bill. "Transnation." Rerouting the Postcolonial: New Directions for a New Millennium, edited by_Janet Wilson, Cristina Sandru \& Sarah Lawson Welsh. Routledge, 2010, pp. 72-85.

Benvenuti, Giuliana. “'Who Needs Italianness?' Postcolonial and Migration Italian Literature.” Identity: Concepts, Theories, History and Present Realities (a European overview), volume 1, edited by Maria Manuel Baptista. Grácio, 2015, pp. 121-38.

Bradbury, Mark \& Healey, Sally. "Endless war: a brief history of the Somali conflict." African Journal on Conflict Resolution, no. 21, 2010, pp. 10-4. www.c-r.org/accord/somalia/endless-war-brief-history-somali-conflict.

Fangen, Katrine. "Humiliation Experienced by Somali Refugees in Norway." Journal of Refugee Studies vol. 19, no. 1, 2006, pp. 69-93. DOI: https://doi.org/10.1093/jrs/fej001.

Fanon, Frantz. The Wretched of the Earth. Trans. C. Farrington. Penguin, 1967.

Farah, Nuruddin. "A Country in Exile." Transition vol. 5, no. 1, 1992, pp. 4-8. DOI: https://doi.org/10.2307/2935151. "Nuruddin Farah" (Interview). Indaba: Interviews with African Writers, edited by Stephen Gray, Protea, 2005, pp. 179-92. Close, Sesame. Allison \& Busby, 1983.

Crossbones. Riverhead, 2011.

North of Dawn. Riverhead, 2018.

Secrets. David Phillip, 1998.

Yesterday, Tomorrow: Voices from the Somali Diaspora. Cassell, 2000.

Fongang, Delphine. "Cosmopolitan Dilemma: Diasporic Subjectivity and Postcolonial Liminality in Teju Cole's Open City." Research in African Literatures vol. 48, no. 4, 2017, pp. 138-54. DOI: https://doi.org/10.2979/reseafrilite.48.4.10.

Fongang, Delphine, ed. The Postcolonial Subject in Transit:Migration, Borders, and Subjectivity in Contemporary African Diasporic Literature. Lexington, 2018.

Gagiano, Annie. "Surveying the contours of 'a country in exile': Nuruddin Farah's Somalia." African Identities vol. 4, no. 2, 2006, pp. 251-68. DOI: https://doi.org/10.1080/14725840600761195.

."Three takes on Somali womanhood in the eddies of the Black Atlantic." Dealing with Evils: Essays on Writing from Africa. $2^{\text {nd }}$ ed. ibidem, 2014, pp. 277-303.

George, Olakunle. African Literature and Social Change: Tribe, Nation, Race. Indiana U P, 2017.

Glanville, Erin G. "Rerouting Diaspora Theory with Canadian Refugee Fiction." Rerouting the Postcolonial: New Directions for the New Millennium, edited by Janet Wilson, Cristina Sandru \& Sarah Lawson Welsh. Routledge, 2010, pp. 128-38.

Ghiroldi, Marta. The Afropolitan Experience in Chimamandi Ngozi Adichie and Igiaba Scego: A Comparative Study. Diss. U Ca'Foscari Venezia, 2017. http://hdl.handle.net/10579/11903.

Juraga, Dubravka. "Nuruddin Farah's Variations on the Theme of an African Dictatorship: Patriarchy, Gender, and Political Oppression in Somalia." Emerging Perspectives on Nuruddin Farah, edited by Derek Wright. Africa World P, 2002, pp. $283-307$.

Hall, Stuart. "Cultural Identity and Diaspora." Identity: Community, Culture, Difference, edited by Jonathan Rutherford. Lawrence and Wishart, 1990, pp. 222-37.

Kleist, Nauja. "Negotiating Respectable Masculinity: Gender and Recognition in the Somali Diaspora." African Diaspora vol. 3 , no.1, 2010, pp.185-206. DOI: https://doi.org/10.1163/187254610X526913. 
Langellier, KM. "Performing Somali Identity in the Diaspora." Cultural Studies vol. 24, no.1, 2010, pp. 66-94. DOI: https://doi. org/10.1080/09502380903200723.

Lara, Maria Pia. Moral Textures. Feminist Narratives in the Public Sphere. U of California P, 1998.

Masterson, John. The Disorder of Things: A Foucauldian Approach to the Work of Nuruddin Farah. Wits U P, 2013.

Moghissi, Haideh. "The 'Muslim' diaspora and research on gender: Promises and perils." Diaspora, Memory and Identity, edited by Vijay Agnew. University of Toronto P, 2005. DOI: https://doi.org/10.3138/9781442673878-015.

Ngaboh-Smart, Francis. Beyond Empire and Nation: Postcolonial Arguments in the Fiction of Nuruddin Farah and B. Kojo Laing. Rodopi, 2004.

Ouzgane, Lahoucine \& Robert Morrell, eds. African Masculinities: Men in Africa from the Late Nineteenth Century to the Present. Palgrave Macmillan, 2005.

Pasura, Dominic \& Anastasia Christou. "Theorizing Black (African) Transnational Masculinities." Men and Masculinities vol. 21, no. 4, 2017, pp. 521-46. DOI: https://doi.org/10.1177/1097184x17694992.

Scego, Igiaba. Adua. Trans. Jamie Richards. New Vessel, 2017.

Shih, Shuh-mei. "World Studies and Relational Comparison". PMLA vol. 130, no. 2, 2015, pp. 430-8. DOI: https://doi.org/10.1632/ pmla.2015.130.2.430.

Stonebridge, Lyndsey. Placeless People: Writings, Rights and Refugees. Oxford U P, 2018.

Svenberg, Kristian, Bengt Mattson \& Carola Skott. “'A person of two countries'. Life and health in exile: Somali refugees in Sweden." Anthropology and Medicine vol. 16, no. 3, 2009, pp. 279-291. DOI: https://doi.org/10.1080/13648470903295984.

Tembo, Nick Mdika. "Reduced to Rubbish: Trauma and Migrant Identities in Cristina Ali Farah's Little Mother." Scrutiny2: Issues in English Studies in Southern Africa vol. 22, no. 2, 2017, pp. 65-81. DOI: https://doi.org/10.1080/18125441.2017.1304438.

Uwakweh, Pauline Ada. "(Re) Configuring African migration since the last forty years. Issues, concepts, and contexts." Engaging the Diaspora: Migration and African Families, edited by Pauline Ada Uwakweh, et al. Lexington, 2013, pp. 1-14.

Victoroff, Jeff, Janice R. Adelman \& Miriam Matthews. "Psychological Factors Associated with Support for Suicide Bombing in the Muslim Diaspora." Political Psychology vol. 33, no. 6, 2012, pp. 791-809. DOI: https://doi.org/10.11l1/j.14679221.2012.00913.x.

Whittaker, Sara, et al. "An Exploration of Psychological Well-being with Young Somali Refugee and Asylum-seeking Women." Clinical Child Psychology and Psychiatry vol. 10, no. 2, 2005, pp. 177-196. DOI: https://doi.org/10.1177/1359104505051210.

Zeleza, Paul Tiyambe. "Diaspora Dialogues: Engagements between Africa and its Diasporas.” The New African Diaspora, edited by Isidore Okpewho \& Nkiru Nzegwu, Indiana U P, 2009, pp. 31-58. 